\title{
Research on the Effects of New Energy Power Generation on Power System
}

\author{
Yong Qian \\ Jinzhou Power Supply Branch \\ State Grid Liaoning Electric Power Supply Co. Ltd \\ Jinzhou, China \\ qianyjz@163.com \\ Chuan Jiang \\ Jinzhou Power Supply Branch \\ State Grid Liaoning Electric Power Supply Co. Ltd \\ Jinzhou, China \\ jiangcjz@163.com
}

\author{
Chunhong Chen \\ Jinzhou Power Supply Branch \\ State Grid Liaoning Electric Power Supply Co. Ltd \\ Jinzhou, China \\ chenchjz@163.com
}

\begin{abstract}
With the continuous development of the social economy, the energy demands of the whole society become larger and larger. Energy shortage and environmental pollution have attracted widespread attention. Under the circumstance of higher energy consumption and the heavy pollution of the traditional electrical power generation, the new energy emerges as the times require. Wind power and solar power will become the new energy industry in the key development areas of development planning. The development of stand-alone power supply of distributed PV and wind energy complemented generation system is outlined with respect to reliability and marketability. This paper introduces the wind power generation technology, solar power generation technology fuel cell power generation technology and biogas power generation technology. Through the simulation, researchers assess the effect of new energy on load wave peak and valley. The research laid the foundation for later practice.
\end{abstract}

Keywords- energy; environmental pollution; electrical; wind power; solar power (key words)

\section{INTRODUCTION}

New energy is a kind of renewable energy, including solar energy, biomass energy, wind energy, geothermal energy, wave energy, ocean current, and tidal power. In addition, coal, oil, natural gas, water and energy have been widely used, which are known as the conventional energy resources. With the limitations of conventional energy and the environment problems, new energy gets more and more world attentions. Development of new energy is taken into account due to energy crisis and environmental pollution, and wind power technology as the fastest growing clean energy is especially popular.

A new energy may form an industry in China, mainly including water energy (mainly refers to the small hydropower station), wind energy, biomass energy, solar energy, geothermal energy, these clean energy may be recycled. The development of new energy industry is not only the effective supplementary means for the whole energy supply system, but also an important measure of environmental and ecological protection; it is the final energy option to meet the sustainable development of human society[1].

Generally speaking, conventional fuels have been massive use of energy; new energy, often referred to as yet the large-scale utilization, is actively research and development of energy. Therefore, the coal, oil, natural gas and large and medium-sized hydropower are considered as the conventional energy; the modern biomass energy, geothermal energy, solar energy, wind energy, ocean energy and hydrogen are considered as a new energy.

According to the analysis, the energy consumption structure in China since 2001 has no significant change. Fossil energy, especially coal consumption in primary energy consumption has been in the dominant position; the share is more than ninety percent and sixty percent respectively.

From the "your best defense is a good offense" file, a Chinese government spokes woman responded to the report by stressingher nation's increasing efforts to develop New Energy[2]. They thought that the government had a more important place to influence the development of new energy than consumer and business ci rcle. For the new energy industry, comprehensive observation of the Chinese stock market industry also demonstrates this point, China's green energy stock prices float in the sky, more idle funds pouring into the new energy and environmental protection industries. At the same time, China will be more than Europe, become the world's largest renewable energy growth markets. Under this background, the new energy industry should seize the opportunity, actively developing wind power, solar energy and so on, to increase the share of new energy. Wind power, solar power will beco me the new energy industry, the key development areas of development planning.

It is estimated that annual solar radiation to the earth is 1.78 billion $\mathrm{kw}$, which can be the development and utilization about $500 \sim 100$ billion degrees. But its distribution is fragmented, which can be used very little. Geothermal resource is total calories of the rocks and water within 5000 meters deep. Geothermal energy, using heat extracted from subsurface sources, has a high 
potential for innovation and development, and could contribute to a sustainable energy mix. Some countries have set out to commercial development and utilization. The world wind energy potential is about 350 billion $\mathrm{kw}$, at first because wind discontinuous scattered, it is difficult to economic advantage, people can lose energy storage technology; if there are any significant improvements in the future, wind use will increase. With the progress of technology, wind power energy in the new technology is one power generation technology which is one of the most mature, most large-scale developments for commercial. Ocean energy such as tidal power, wave energy, sea water energy, reserves is very considerable. Limited to the technical level, now people is still in the stage of small study. The current due to the use of new energy technology is not mature, so the world needs only a small part of total energy which has great prospects in the future [3].

\section{THE NEW ENERGY POWER GENERATION TECHNOLOGY}

New energy is kind of renewable resources. The development of new energy industry is not only the effective supplementary means in the whole energy supply system, but also an important measure of environmental and ecological protection, to the final energy choice for the sustainable development of human society. New energy includes wind, solar, fuel cell and gas.

\section{A. Wind power generation technology}

The wind is a kind of renewable, no pollution and huge reserves energy in the nature. According to a rough estimate, the recent available overall wind power is about 106MW 107MW.

First, putting he kinetic energy of the wind into mechanical kinetic energy, and then put the mechanical energy into electricity kinetic energy, this is wind power. The principle of wind power generation is using wind power to drive the windmill blades rotating, then the growth machine will increase the speed of rotation, making generator to produce electricity. According to the current versions of the windmill, it is wind speed (the extent to which the breeze) about three meters per second, can then produce electricity. Wind power becomes a boom in the world, because the wind power does not need to use the fuel, also won't produce radiation or air pollution [4].

Wind power device is called a wind turbine. This kind of wind generating can be divided into wind turbines (including stern rudder), generators and tower three parts.

Wind turbines are an important part of the wind's kinetic energy into mechanical energy, which is composed of two propeller type impeller. When the wind blows to the blade, aerodynamic force will drive rotor rotation. Blade material requirements high strength and light weight, the multi-purpose fiberglass or other composite materials are used widely.

\section{1) The use of wind power}

The wind power is used in two forms, respectively of wind driven electric and wind power. Priority is given to the wind power; all kinds of machinery put the wind as drive, realizing wind energy to mechanical energy conversion. Such as windmills pumps carry water and so on. In many countries, they also use wind energy for aquaculture and wind power production.
Denmark is one of the world's largest producers of wind power generators. China is rich in wind energy resources. Wind energy resources are mainly distributed in Xinjiang, Inner Mongolia and other northern and eastern coastal areas. The best areas concentrated in the coastal area, Inner Mongolia, Gansu and northeast area.

2) Principle of wind power

The principle of wind power is the energy conversion, converting the kinetic energy of the wind into mechanical energy, and then converting mechanical energy into electricity.

\section{B. Solarpower generation technology}

The sun is the eternal energy of the earth, also a kind of no pollution, clean energy. There are many ways of utilizing solar energy, like solar power, solar energy heat utilization, solar energy utilization and utilization of solar energy light-light, etc. Using the sun's light energy or heat energy to produce electricity is called solar power.

Solar energy is energy from earth's external objects (mainly solar); the hydrogen nuclei fusion of the sun released the great energy under the ultra high temperature, and the vast majority of human energy is directly or indirectly from the sun. Researchers are living for fossil fuels such as coal, oil, natural gas because of all kinds of plant through photosynthesis convert solar energy into chemical energy in plant body storage down, again by the plants and animals buried in the ground after the long geological s form. In addition, hydropower, wind energy, wave energy, ocean currents can also came by solar energy conversion.

Solar power is a device which put converting solar energy directly into electricity through the use of battery components [5]. Solar modules are a solid device which realizes $\mathrm{P}-\mathrm{V}$ conversion by the use of characteristics of semiconductor electronics implementation. In the vast network, the device can conveniently realize lighting and power supply for the user, and some developed countries can also be complementary with regional power grid interconnection.

\section{1) Photovoltaic power generation}

Convert light energy into electrical energy directly by photoelectric conversion device called a "solar power" or "photovoltaic".

Solar photovoltaic is a way of power generation solar energy directly into electrical energy. It includes photovoltaic power generation, photochemical power generation, light induced biological generation, and light in the photochemical generation; in electrochemical photovoltaic cells it includes electrochemical photovoltaic cell, photo electrolytic cell and photo catalytic battery.

Currently the most widely used solar power generation is solar photovoltaic power generation; its principle is to use the sun's energy directly to generate electricity.

Solar photovoltaic battery power is considered to be the fastest and most promising new renewable energy technologies in the future. Its basic principle is to use the photovoltaic effect of semiconductor converting light energy to electricity. The conversion device called solar photovoltaic cells, photovoltaic cells is the core of photovoltaic components.

Solar photovoltaic power station is packaging a number of photovoltaic cells to photovoltaic cell 
components. According to the need to several components combined into a certain power of $\mathrm{P}-\mathrm{V}$ array.

Photovoltaic power generation system is mainly composed of solar battery, storage battery, controller and inverter; the solar cell is a key part of the photovoltaic power generation systems, quality and cost of solar panels will directly determine the quality and cost of the whole system. Solar cells is mainly divided into two categories, crystalline silicon cells and thin film battery; the former includes single crystal silicon and polysilicon batteries, the latter mainly includes the amorphous silicon solar cells, copper indium gallium selenide solar cells and cadmium telluride solar cells [6].

\section{2) Solar thermal power generation}

Solar thermal power generation technology is to convert solar radiation heat energy into electrical energy power. Solar thermal power generation by solar collection methods can be divided into solar tower thermal power generation, power generation solar trough type and solar butterfly thermal power generation.

Tower solar thermal power generation system is in the middle of the open ground to build a tall absorption tower. Fixed an absorber installed on the top of the tower. Install a certain number of heliostat around the tower. Gather the sun's light onto the top receiver cavity in the body to produce high temperature through the heliostats, through a heat absorber of working medium and high temperature steam produced to push the turbine to generate electricity.

Trough type solar power generation device is a kind of using slotted parabolic mirror reflect focusing the sun's light onto the area, then through the tube heat carrier to take away heat and heat water to produce steam, steam turbine generating device.

Butterfly solar thermal power generation technology in solar thermal power generation is a way which has the highest photoelectric conversion efficiency. It with the aid of two-axis tracking, the received solar power concentrated in the focus of the receiver by parabolic butterfly mirror. Receiver absorbs this part of the radiant energy and converts it into heat energy.

\section{Fuel cell power generation technology}

Fuel cell is a kind of device which may convert chemical energy stored in the fuel and oxidant directly into electrical energy. Since it has high power generation efficiency and good environmental performance, has been actively developing in recent years.

\section{1) Fuel cell classification}

The nature of the fuel cell can be divided into different types according to the electrolyte. Each type of fuel cell need special material and fuel, and applied to different occasions. According to the electrolyte, the fuel cell is roughly divided into five types, proton exchange membrane fuel cell, alkaline fuel cell, acid fuel cell, molten carbonate fuel cell and solid oxide fuel cell.

\section{2) The working principle of the fuel cell}

The principle of fuel cell is similar to normal cells. It is composed of positive and negative two electrodes and electrolyte monomer battery. Electrolyte to separate two stages, conductive movement within the electrolyte ions, electrons through the external circuit and electric circuit doing work

\section{Biogas power generation technology}

Biogas burning power generation is a biogas utilization technology with the large-scale construction and development of comprehensive utilization of biogas pool; it puts a biogas of anaerobic fermentation processing use on the engine, and it is equipped with integrated power generation device to generate electricity and heat. Biogas power generation has the characteristics of gen efficiency, energy saving, safety and environmental protection, it is a widely distributed energy at a low price [7].

Biogas is a kind of renewable clean energy and has the high calorific value. Antiknock performance is better than other fuel. Biogas widely used in rural, such as methane gas for heating, cooking and lighting. With the continuous development of new energy technologies, biogas power generation technology has been widely studied. Biogas power generation is take methane as engine fuel. Drive the generator to produce electricity. Currently used in biogas power generation equipment mainly include internal combustion engines and steam turbines.

Research and development of biogas power generation in China have a history of more than 20 years and a certain progress has been made. Shandong Province connected the first sludge biogas generator set successfully to the grid, and solved the problem of the sewage treatment plant sludge disposal, because the development of circular economy has played a positive role. In the remote rural and pastoral areas, islands and remote mountain area with small biogas generator power generation can solve the problem of power shortage.

Research and development of biogas power generation in China have a history of more than 20 years. The current domestic $5000 \mathrm{kw}$ capacity of biogas power generation units at all levels have been successively identified and put into production, the main products have use the biogas pure methane and biogas dual-fuel engine gas - diesel engines. The units $h$ has its own characteristics, each have the breakthrough of technology and novel structure, have used in some rural, organic wastewater, landfill biogas engineering systems. In recent years due to the responsibility system for rural households, large and medium-sized factory of livestock farm building and environmental protection, the biogas, biogas generator set in China has developed toward the poles. Rural mainly 3$10 \mathrm{kw}$ biogas and biogas generator set direction, and the winery, sugar mill, livestock farm, sewage treatment plant of large and medium-sized energy environmental protection projects, mainly in single capacity of 50-200 kw gas generator set direction.

\section{THE INFLUENCE OF NEW ENERGY POWER GENERATION ON THE SYSTEM}

The accessing of new energy aims at reducing electric energy generated from fossil fuel power plants if the safety and reliability of power supply are ensured. But power generated from new energy effect by natural factors on the timeline, belonging to unscheduled. The ideal condition is that when the load is in a peak period, the new energy power gets the maximum, and when the load is in valley period, the new energy power gets the minimum. However, after large amount of data tests and researches, the effect of new energy accessing on load system is found including positive peak effect, negative peak effect and overload 
peak effect. Fig. 1 is the simulation analysis of positive peak effect. The setting of wind power generation is 0.5 times of initial curve, and photovoltaic power generation is 0.15 time. In the period of 1 15 and 46 60 wind power generation doesn't work. To simplify the problem, lower limit of power the fossil fuel power plants generated is assumed as the minimum load. From the figure, energy output of fossil fuel is constant in valley period, but in the peak period, the energy output of fossil fuel reduces due to the participation of new energy [8]. The final result is that the difference between peak value and valley value reduces; therefore, its spinning reserve capacity can reach the purpose of saving fossil fuel with an appropriate decrease, which is a good way of new energy access.

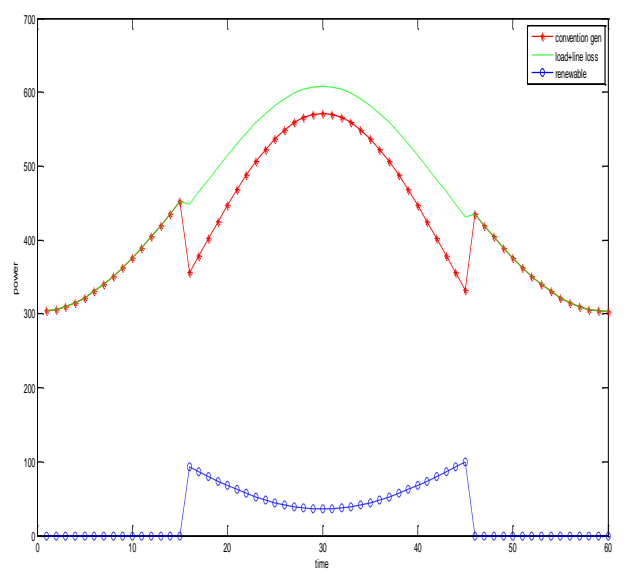

Figure 1. Positivepeak effect of new energy power generation access

Fig. 2 is negative peak effect, the setting of wind power generation is 0.5 times of initial curve, and photovoltaic power generation is 0.15 time. In the period of $15 \sim 45$ wind power generation and photovoltaic power generation don't work. From the figure, energy output of fossil fuel is constant in peak period, but in the valley period, the energy output of fossil fuel pierces the lower limit due to the participation of new energy. The final result is that difference between peak value and valley value increases, its power lower limit should adjust in power cut direction. If the power lower limit generated by power station is bound by objective conditions and cannot be adjusted, the security of the systemwill be threatened [9].

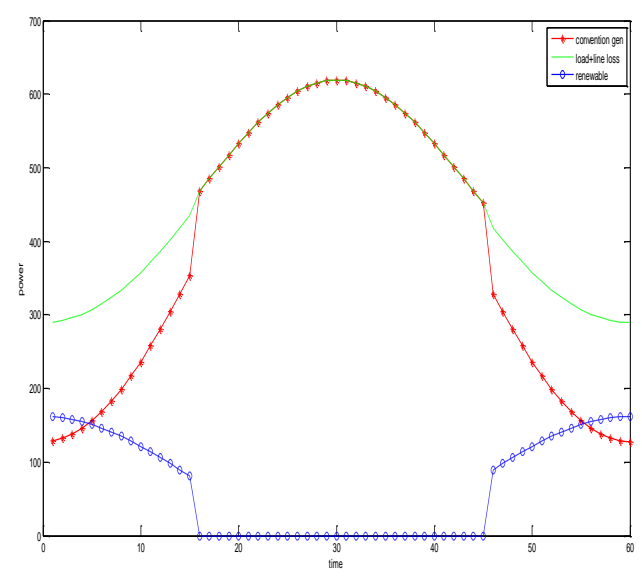

Figure 2. Negative peak effect of new energy power generation access
Fig. 3 is overload peak effect, the setting of wind power generation is 0.8 times of initial curve, and photovoltaic power generation is 0.5 time. In the period of $1 \sim 15$ and 46 60 wind power generation and photovoltaic power generation don't work. From the figure, energy output of fossil fuel is constant in valley period, and in the peak period, the energy output of fossil fuel reduce due to the participation of new energy. But due to the big capacity connecting to network of new energy power generation, the energy output of fossil fuel pierces the lower limit in some periods, and the security of the system will be threatened.

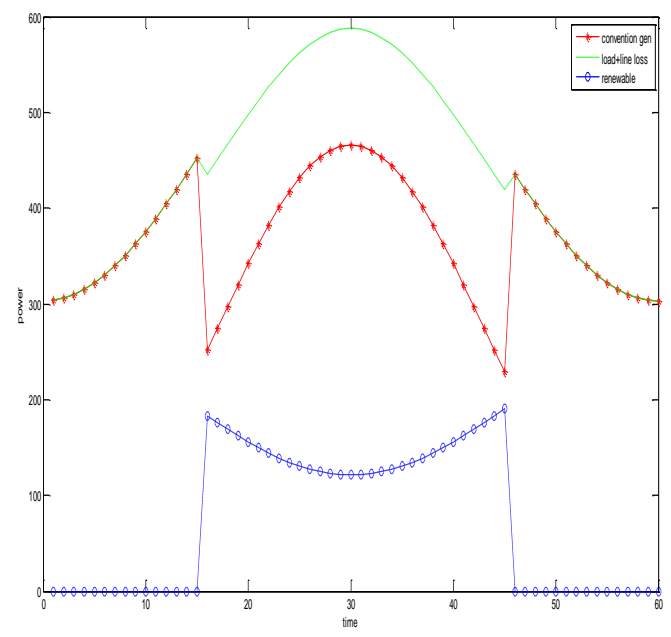

Figure 3. Overload peak effect of new energy power generation access

Single type of new energy power generation has the obvious feature that power fluctuation is greater. For example, the feature of the photovoltaic power generation in a day is: when altitude of the sun is the lowest, photovoltaic panels generate maximum power; photovoltaic panels don't work at night. If photovoltaic power generation capacity in a system is large, power output will have a drastic fluctuations, and system realtime power control will become very difficult [10]. In order to overcome shortcoming of single new energy power fluctuation greatly, many scholars present a concept of hybrid renewable energy. In these theories, the research of wind and solar hybrid generation is most. But what need to be highlighted is that wind power generations are assumed to generate full power at night, but less power or no power in the day in the most of papers. They also assume that wind power can compensate for gaps of photovoltaic energy at night, and photovoltaic energy can compensate for gaps of wind power in the day.

\section{CONCLUSIONS}

With the development of technology, a lot of progresses have been made in the new energy power generation technology. Wind power generation is one of the most sophisticated means of power generation in technology with best prospects for commercial development among the means in which new energy recourses is employed. Solar power plant is one of the most important forms of developing and utilizing the renewable energy resources. Wind power and solar power 
will become the new energy industry, a key development area of development planning.

\section{REFERENCES}

[1] L.Huang, Y.H.Zhang. Germany's new energy development strategy enlightenment to China [J]. Resources and industry. 2010, $10(03): 48-53$

[2] Q.Yan. In developing new energy barriers and response: global stat us are reviewed [J]. Journal of earth. 2010,10(05):759-767.

[3] C.X.Li, J.Wang. New energy development present situation and prospects in China $[\mathrm{J}]$. Electric power science and engineering, 2012,.5(04).1-8.

[4] Keane A, O'Malley M. Optimal Allocation of Embedded Generation on Distribution Networks[J]. Power Systems, IEEE Transactions on, 2005,20(3):1640 - 1646.
[5] L.Ding, Z.C.Pan. The influence of dispersing power grid for power supply reliability analysis [J]. Automation of electric power systems. 2007, 20(4):89-93.

[6] H.Che., Progress in electrical energy storage system: A critical review[J]. Progress in Natural Science, 2009, 19(3): 291-312.

[7] Y.Yuan, Q.Li. Optimal Operation Strategy of Energy Storage Unit in Wind Power Integration Based on Stochastic Programming[J]. Renewable Power Generation, ,2011,5(2):194-201

[8] Díaz-González F, Sumper A, Gomis-Bellmunt O. A review of energy storage technologies for wind power applications [J]. Renewable and Sustainable Energy Reviews, 2012, 16(5):2154 2171.

[9] Hedegaard K.,Meibom P. Wind power impacts and electricity storage-A time scale perspective[J]. Renewable Energy, 2012,37(1):318-324

[10] L.C.Lu. New energy landscape power prediction model research [J]. North China electric power university, 2013, 10(20): 7-12. 